\section{The Meaning of Growing Plants: Contributions to the Elderly Living in Sheltered Housing}

\author{
Erja Rappe ${ }^{1}$ and \\ Aino-Maija Evers ${ }^{2}$
}

\begin{abstract}
Additional index words. people and plants, the elderly, institutional environment, autonomy, identity, social relationships, human issues in horticulture
\end{abstract}

\begin{abstract}
Summary. In this qualitative research conducted in Finland, 12 residents in sheltered housing for aged people were interviewed to explore the meanings they associate with the growing of plants. Growing plants had both individual and social meanings for the interviewees. The individual meanings were categorized into three groups: one's own growing skills, the continuity of time, and creating experiences. The category “one's own growing skills" was coded into three subcategories: individual settings and growing methods, interpretation of the plants' needs and responses, and adaptation to current situation. The social meanings identified in the data were also divided into three categories: significant acts undertaken for other people, indications about the gardener, and the feeling of togetherness. The results of the research suggest that growing plants may have an effect on the wellbeing of the elderly who have a rural background and are living in institutional settings, especially for those aspects threatened by institutional environments: autonomy, a sense of control, identity, and the opportunity to form social relationships.
\end{abstract}

\footnotetext{
We would like to acknowledge Antti Hervonen for his advice and support and Leena Lindén for her suggestions and for her reading of the manuscript. This research was supported in part by Agronomiliitto, Finnish Association of Academic Agronomists. The cost of publishing this paper was defrayed in part by the payment of page charges. Under postal regulations, this paper therefore must be hereby marked advertisement solely to indicate this fact.

${ }^{1} \mathrm{PhD}$ student, Vehkakoskentie 29, 42850 Pohjaslahti, Finland; e-mail erja.rappe@helsinki.fi.

${ }^{2}$ Dr., dos. horticulture.
}

$\mathrm{G}$ ardening has long been one of the most common spare-time activities among elderly people (Hill and Relf, 1982; Sarola, 1994). However, in modern institutional care-facilities for the elderly, the residents' opportunities for continuing their hobbies are limited. This raises the question of whether or not growing plants could contribute to the well-being of the elderly living in institutional settings.

Health facilities have customarily been designed to be effective careenvironments, but these environments are also often psychologically stressful (Ulrich, 1991). The design of the grounds is usually highly institutional, which can aggravate the residents' problems of isolation, loneliness, and loss of capability and identity (Stoneham and Thoday, 1996). Moreover, conflicts between the residents' autonomy and security are particularly prominent in homes for the elderly (Päivärinta, 1997). The life of the elderly in long-term care is often thus marked by loneliness, social isolation and by the feelings of worthlessness (Noro, 1998). According to Grahn (1991), an elderly person in institutional care may often adopt a passive role as a dependent. The abilities of the elderly become impaired, when the environment accepts them as decrepit instead of supporting their identity. Furthermore, the emphasis placed on diseases in health care work strengthens this role of decrepitude in the elderly (Liukkonen, 1995; Stein, 1997).

Does gardening have qualities which could affect positively the institutional environments of elderly people? Gardening, when regarded as interaction between people and plants, includes both physical and psychological activities. The main content of gardening is the fostering of a living thing (Browne, 1992; Lewis, 1992, 1996; Matsuo, 1995). Horticultural activity enables individual creativity, social interaction (Browne, 1992) and the reciprocal exchange relationships with other people (Lewis, 1996; Stein, 1997). Stein (1997) states that by gardening, residents in a nursing home may create new memories and meanings for their lives. Plants may also trigger pleasant memories from the past (Browne, 1992; Lewis, 1996). Gardening may also increase opportunities for independent choice (Stein
1997). Ulrich (1991) suggests that to promote wellness, the environment in healthcare facilities should foster a sense of control, access to social support and access to positive distractions. In addition, plants give the elderly a hope for the future (Gaskins and Forté, 1995; Lewis, 1996). The change, which appears in the growth of the plants, can be experienced as something favorable, not threatening like the change in health of the elderly (Lewis, 1996).

To assess whether growing plants contributes to the well-being of elderly living in institutions, we examined whether the growing of plants has meanings for the elderly that can be associated with their well-being. It is widely accepted that nature and plants contribute to human well-being (Relf, 1992). The effects of this positive benefit are often studied by measuring blood pressure and pulse and by using other tests (e.g., Hartig et al., 1991; Ulrich et al., 1991; Lohr et al., 1996; Ottosson and Grahn, 1998). However, these methods cannot reveal all the aspects of how the experience of growing plants affects human wellbeing. This study, therefore, applies a qualitative approach to clarify how elderly people themselves experience plants and nurture of plants in an institutional environment of sheltered housing.

Rowles (1984) has defined the concept of environmental experience as "physical, cognitive, and emotional transactions with the physical setting". In this study, the experience of growing plants is defined analogous to Rowles' (1984) definition as a physical, cognitive, and emotional interaction of the elderly with plants. The interaction of the elderly with plants means either the actual growing or the mental activity involved in nurturing a plant. The question of whether or not the meanings the elderly give for growing plants can be associated with the well-being of residents is explored in this study. Especially those aspects of human well-being threatened in institutional environments, such as autonomy, identity, and social relationships are emphasized in the present analysis.

\section{Subjects}

The 12 subjects in this study were all residents in a sheltered housing area located in the center of a small rural commune and were mainly natives of 
the neighboring countryside. The staff of the facility helped to choose the participants for the study. The participants were required to be capable of communicating and without severe impairments. Both gardening enthusiasts and those not interested in growing plants were sought for the study. All residents who were asked to participate agreed. Eight of the interviewees selected were women and four were men. The average age was 80.6 years; the youngest interviewee was 68 years and the oldest was 88 years of age. The participants had lived in sheltered housing from 2 to 24 years, the average being 11.6 years. All interviewees lived alone.

The sheltered housing area consisted of 55 dwellings in four terraced houses. The outdoor settings of the facility included a few large trees, a sitting area with plants and some resting places. The main outdoor-activities of the residents were gardening, walking and talking with others. The residents were offered the possibility to grow plants in beds under their windows and indoors. All the interviewed were capable of engaging in horticultural activity if they so wanted. The participants grew mainly flowering annuals and perennials, but some of them also grew vegetables. The growing of vegetables took place usually somewhere outside the sheltered housing area. Some of the residents had potted flowers as well as cut flowers indoors. All the interviewees had become acquainted with the growing of plants during their childhood. Eight interviewees had earned their living at least partly by farming.

\section{Methods}

The data for the study were collected by a theme-interview (Hirsijärvi and Hurme 1995) and by observation. The interviews were conducted in August 1997 by the first author in the homes of the participants. The average duration of an interview was $1.5 \mathrm{~h}$. Information was requested on age of the interviewees, theirimpairments, their dwelling-time in sheltered housing and their life histories. The main theme of the interview was the resident's relationships to plants. Relationships to his or her environment, and to the community he or she was living in and the community's relationship to plants were additional themes. The order and the extent of the themes varied, depending on the context of the interview. The interviews were taped and transcribed verbatim when the statements concerned the themes. In the course of the interviews, the interviewer made observations about their plants. Notes about observations were written down after each interview. The age of the interviewees and their dwelling-times in sheltered housing were verified by consulting with the administration of the facility.

When reviewing the literature on this subject, no research was found concerning the meaning that growing of plants has for the elderly. The method of Grounded Theory (Glaser and Strauss, 1971) is suitable to apply in studies concerning unknown issues. In this study the first stage of the data analysis involved the reading of the transcribed interviews and producing corresponding mindmaps of the relationships between each interviewee and the plants. The mindmaps helped to discover preliminary categories for the data classification. The data were then coded using the method of continuous comparison (Glaser and Strauss, 1971). By reading the data repeatedly, new categories emerged and the connections between categories were clarified. When coding the data, emphasis was placed on actions, thoughts, and feelings related to the resident's own growing of plants or to the growing of plants by other residents.

\section{Results}

The meanings which interviewees connected to the experience of growing plants were coded into six main categories representing three individual and three social meanings (Table 1 ). The category “one's own growing skills", which played a central role in the individual meaning, was divided into three subcategories according to the goals pursued. Generally, growing plants enabled the interviewees to use their cognitive skills widely and to have various emotional experiences. Plants and nurturing them played a significant role in the social relations among the interviewees. Growing activities and the interviewees' ability to understand the cues of plants maintained their interaction with environment (Table 1).

\section{Individual meaning One's own growing skills} InDIVIDUAL SETTINGS AND GROWING METHODS. There were no rules concerning the growing of plants in the community and the interviewees were allowed to grow any plants they wanted under their windows. Every flowerbed was of a different style, depicting the preferences of the grower. Individuality appeared in the choice of the species and in growing methods. Various growing methods were applied in accordance with how necessary they were considered to be. Some of the interviewees only watered plants so that they survived, but others also used fertilizers, removed old flowers, sprayed leaves with water, and protected plants against the hot sun. The interviewees were clearly aware that each of them had their own growing methods.

INTERPRETATION OF THE PLANT'S NEEDS AND RESPONSES. One's individual growing skills were used to understand the response of the plants and to adjust activities to meet the needs of plants. Interviewees could estimate the influence that weather conditions, pathogens, pests, and the choice of species had on the need for nurturing and the success of growing. One's own activities were also changed by experience. By interpreting the response of the plants, the interviewees also evaluated their own cultivation techniques.

Adaptation. The residents' individual growing skills were used to adapt the growing plants to the environment and also to tailor their own individual restrictions caused by aging and impairments. The interviewees were highly competent to evaluate how suitable the environment was for growing. They grew species they expected to succeed in those conditions. Growing conditions indoors could be evaluated to be so poor that an interviewee abandoned growing plants and used artificial flowers. The interviewees had developed growing methods to facilitate their activities. They stated that would their state of health deteriorate, they would cut down the growing of plants or lower the standard of nurturing. Interviewees maintained that the growing of plants would come to an end when they could no longer nurture the plants by themselves.

\section{Continuity of time}

Time was linked to plant growing in connection with memories, prospects, and continuity. For the interviewees, the past, the present, and the future were all in the plants. Some participants had brought potted flowers or perennials to the elderly housing from their 
earlier homes. Although the interviewees had a cautious attitude towards the future and doubts concerning their own state of health, the plants gave rise to positive expectations. The elderly residents looked forward to the flowering of plants, harvest and to the next springtime.

\section{Creating experiences}

Plants and nurturing them brought aesthetic and emotional experiences to the interviewees. Both women and men considered flowers to be beautiful and liked looking at their own flowers or the flowers of other growers. It was considered fascinating and interesting to follow the growth of the plants. To see living proof of their success was a reason for satisfaction. Men considered growing activities as their duty. The plants were an object of caring, especially for women. Plants also offered a way to express caring and loving for other people. Furthermore, the plants children had given to the interviewees were of special significance and they were cherished carefully.

\section{Social meaning}

\section{Significant acts for other people}

Significant acts for other people were important for the interviewees. Plants, seeds, services, and advice were given and received. The interviewees helped others in planting and nurturing. They praised each other for their good growing results and appreciated these comments highly when they received them. The activities connected with growing plants offered an opportunity to create various roles in the community. For example, a woman who had plenty of plants was considered as an expert and others asked her for help and advice.

\section{Indications about the gardener}

Plants revealed the different features of their growers for those who were looking at them. The plants could reveal to other residents how capable the grower was, what was her or his state of health, how wealthy she or he was, and how well the relatives took care of her or him. In some cases it could be seen that the grower was consciously using plants to tell others things he or she wanted. By comparing their plants with others the interviewees could define their own position in regard to other residents.

\section{Feeling of togetherness}

The interviewees' childhood and adult lives were closely associated with agriculture. The competence of growing formed a collective identity and strengthened the sense of togetherness. Sharing a common world of experience in the growing of plants, the residents consequently understood each other. After all, the plants were a current, familiar and safe topic of conversations.

\section{Discussion}

The qualitative data collected indicates that the meanings the interviewees connected with the growing of plants could be associated with their well-being. The use of one's own growing skills and evaluation of plants grown by others, experiences con-

Table 1. The meanings, which the elderly in sheltered housing attached to the growing of plants: the categories with examples of statements

Individual meaning

One's own growing skills

a) Individual settings and growing methods

"I now have only petunias because they are growing so well."

"I use that special fertilizer with water."

b) Interpretation of the plant's needs and response

"But those geraniums can be without watering two days, they are so modest."

"I watered Saintpaulia too much and it died. I have a habit of watering plants too much."

c) Adaptation

"I have noticed that these artificial flowers are best."

"I have to restrict plants indoors because they aggravate my breathing problems."

I must always smell the plants first [if they are suitable].”

Continuity of time

"I brought those plants from home."

"I have bought seeds of flowers early enough in winter, when the selection is comprehensive."

Creating experiences

"I am caring those flowers because I have no husband to care."

"This [potted plant] I got last Christmas. It was very little then. I have tried to nurse it as well as I can and it has survived."

"Flowers are feast for the eye."

Socialmeaning

Significant acts for other people

"Yes they come to admire the blooming flowers and praise them very much."

"He said last autumn that if I need seeds, I just go to pick them from his flowerbed."

Indications about the gardener:

"...she has always so beautiful flowers. She buys so many plants and changes them if they are withering. They [flowers] are beautiful, if one can afford money."

"There are people who do not have plants. They move so poorly that they can not nurse them [plants]."

A feeling of togetherness:

"I am not the only one who has complained that pansies do not succeed."

"Sometimes we talk about plants when we are sitting on the bench. Yes, it [talking about plants) is very usual." 
nected with plants and feeling of continuity may strengthen the identity of the elderly, as well as promote their sense of autonomy, and their control of the environment. The growing of plants may also encourage social relations by creating possibilities for various roles and by strengthening a feeling of togetherness. The results indicate that growing plants may contribute to the social and psychological well-being of the elderly living in institutions. This is in agreement with other researchers dealing with issues of people-plant interactions (e.g., Browne, 1992; Lewis, 1996; Stein, 1997).

All participants of the study had plants. Even those who were anticipated not to be interested in growing plants owned them. A woman, who reported that she did not care about plants at all grew her own plants and nurtured a rubber plant of a neighbor. Earlier in their lives, most of the interviewees had grown plants mainly to provide food for their families. Now in an institutional setting, they did not grow plants to achieve economical or nutritional benefits but for more subjective reasons.

To promote the well-being of residents in institutional settings, the environment should support their identity, autonomy and social relationships. In this study, the participants' identities were strongly related to their competence in growing plants. The environment which enabled the growing of plants supported the continuity of their identity as growers and prevented the negative consequences which could result if their identity was solely as a resident in a sheltered housing. Other residents drew conclusions about the interviewees as people from their plants. They were aware of this and used plants to tell others about their own skills and preferences. This kind of use of plants can be regarded as the nonverbal articulation of identity mentioned by Baars (1998).

The autonomy of residents living in institutions is restricted (Lawton, 1985; Päivärinta, 1997; Stein 1997). Launis (1994) has divided this autonomy into three dimensions. The first is the autonomy of thinking, which is associated with a person's ability to consider things rationally and to understand the results of his or her own action. The second dimension is the autonomy of wishing, which is the ability to form one's own preferences and evaluate them critically. The third dimension is the autonomy of action, which means the capability to carry out the plans one has made. Growing plants supported the interviewees' autonomy in all three dimensions. The autonomy of thinking was realized in their ability to understand the reactions of plants and the way the plants responded to nurturing. The fact that there were no rules in the community regarding plant cultivation was important for the interviewees. The individual choice of species and growing methods supported the autonomy of wishing. Growing plants enabled individual interaction with the environment. The capability to make interpretations from the response of the nurtured plants and to make adjustments to one's activities accordingly, as well as the capability to adapt to aging, all supported the autonomy of action. According to Lawton (1985), "the more one knows about one's environment, the more autonomous one can be for any given level of competence."

Constant environmental experiences of the elderly support their sense of control and competence (Golant, 1984). Consequently, this sense of control fosters their well-being (Ulrich, 1991). The interviewees were used to growing plants. This cultivation usually gave them successful experiences and seldom did the residents experience failure. The interviewees understood the causes and consequences of events connected with their plants and could anticipate the future. As a result, the experience of competence and success felt by interviewees contributed to their sense of control over their environment.

Furthermore, Ojala (1989) states that the feeling of being needed constitutes a central indicator of the perception of a high quality of life in old age. Residents in the homes for elderly often feel lonely and worthless (Noro, 1998). Yet, these interviewees felt themselves to be necessary not only for the plants well-being, but for the other residents as well. The participants also helped each other in the growing activities and gave horticultural products to others. According to Ojala (1989), meaningful roles that give content to life prevent the elderly from being depressed from the feeling that they are not needed. In this community, growing plants created various roles and activities and thereby promoted social relationships.

Some caution is needed in assessing the results of this study. First, there were only 12 interviewees who were selected to participate. All had experience and had learned growing skills at an early age and all but one had lived in countryside or in a small town. Even the only interviewee who had lived in a city had her roots in the countryside and had spent her vacations in a summer cottage. The dwelling-times of the interviewees in sheltered housing were long (only two participants had lived there less than 8 years). Hence the community they formed was exceptionally well-established.

Since all interviewees grew plants, this brings about the question of whether growing plants was a social norm in the community. Was there a risk to be excluded if one had no plants? Or was the growing of plants a result of the restricted opportunities for other outdoor activities?

The analysis of the data is based on a coding of the statements into various categories. This kind of method always includes factors attached to the researchers and their perspectives.

The subjects in this study were rural elderly who were in relatively good health. Further research is needed to examine the interaction of plants and elderly of different states of health in various contexts. Regarding forthcoming studies, one should bear in mind that the elderly are constantly changing: the next cohorts becoming old are not so accustomed to growing. This, in turn, may have an effect on the meanings connected to plants.

\section{Literature cited}

Baars, J. 1998. Aika, gerontologia ja vanheneminen. Gerontologia 12(2):7281 .

Browne, C.A. 1992. The role of nature for the promotion of well-being of the elderly. In: D. Relf (ed.). The role of horticulture in human well-being and social development. Timber Press, Portland, Ore.

Gaskins, S. and L. Forté. 1995. The meaning of hope: Implications for nursing practice and research. J. Gerontol. Nursing 21 (3):17-24

Glaser, B.G. and A.L. Strauss. 1971. The discovery of grounded theory: Strategies for qualitative research. 4th ed. Aldine, New York. 
Golant, S.M. 1984. The effects of residential and activity behaviors on old people's environmental experiences. In: I. Altman, M.P. Lawton, and J.F. Wohlwill (eds.). Elderly people and the environment. Plenum Press, New York.

Grahn, P. 1991. Om parkers betydelse. Stad \& Land nr. 93. Sveriges lantbruksuniversitet, Institutionen för landskapsplanering, Alnarp.

Hartig, T., M. Mang, and G.W. Evans. 1991. Restorative effects of natural environment experiences. Environ. Behavior 23(1):3-26

Hill, C.O. and P.D. Relf. 1982. Gardening as an outdoor activity in geriatric institutions. Activities, Adaptations and Aging $3(1): 47-54$.

Hirsijärvi, S. and H. Hurme. 1995. Teemahaastattelu. Yliopistopaino, Helsinki.

Launis, V. 1994. Kenelle itsemääräämisoikeus kuuluu. In: J. Pietarinen, V. Launis, J. Räikkä, E. Lagerspetz, M. Rauhala, and M. Oksanen (eds.). Oikeus itsemääräämiseen, Painatuskeskus, Helsinki.

Lawton, M.P. 1985. The elderly in context. Perspectives from environmental psychology and gerontology. Environ. Behavior 17(4):501-519.

Lewis, C.A. 1992. Effects of plants and gardening in creating interpersonal and community well-being. In: D. Relf (ed.). The role of horticulture in human wellbeing and social development. Timber Press, Portland, Ore.

Lewis, C.A. 1996. Green nature/human nature. The meaning of plants in our lives. University of Illinois Press, Urbana and Chicago.

Liukkonen, A. 1995. Life in a nursing home for the frail elderly. Clinical Nursing Res. 4(4):358-372.

Lohr, V.I., C.H. Pearson-Mims, and G.K. Goodwin. 1996. Interior plants may improve worker productivity and reduce stress in a windowless environment. J. Environ. Hort. 14(2):97-100.
Matsuo, E. 1995. Horticulture helps us to live as human beings: providing balance and harmony in our behavior and thought and life worth living. Acta Hort. 391:1929.

Noro, A. 1998. Long-term institutional care among Finnish elderly population. Stakes, Res. Rpt. 87. Gummerrus Kirjapaino OY, Jyväskylä.

Ojala, T. 1989. Livskvaliteten i ålderdomen. Folkpensionsanstaltens publikationer ML:92, Åbo.

Ottosson, J. and P. Grahn. 1998. Utemiljöns betydelse för äldre med stort vårdbehov. Stad \& Land nr 155. Förvaltningsavdelningens repro vid SLU, Alnarp.

Päivärinta, E. 1997. Vanhainkodeista palvelutaloihin- tilat ja toimintaympäristöt toimintaa ohjaavien periaatteiden kuvaajina. Gerontologia 11(3):218-225.

Relf, D. 1992. Human issues in horticulture. HortTechnology 2(2):159-171.

Rowles, G.D. 1984. Aging in rural environments. In: I. Altman, M.P. Lawton, and J.F. Wohlwill (eds.). Elderly people and the environment. Plenum Press, New York.

Sarola, J.P. 1994. Asuinympäristön ja paikan merkitys vanhalle ihmiselle. In: A. Uutela and J.-E. Ruth (eds.). Muuttuva vanhuus. Gaudeamus, Helsinki.

Stein, L.K. 1997. Horticultural therapy in residential long-term care: applications from research on health, aging and institutional life. In: S.E. Wells (ed.). Horticultural therapy and the older adult population. The Haworth Press, Inc., New York.

Stoneham, J. and P. Thoday. 1996. Landscape design for elderly and disabled people. Garden Art Press, U.K.

Ulrich, R.S. 1991. Effects of interior design on wellness: Theory and recent scientific research. J. Health Care Interior Design 3:97-109.

Ulrich, R.S., R.F. Simons, B.D. Losito, E. Fiorito, M.A. Miles, and M. Zelson. 1991. Stress recovery during exposure to natural and urban environments. J. Environ. Psychol. 11:201-230. 